\title{
Multi-Scale Measurements of Neolithic Ceramics-A Methodological Comparison of Portable Energy-Dispersive XRF, Wavelength-Dispersive XRF, and Microcomputer Tomography
}

\author{
Julia Menne ${ }^{1, *(D)}$, Astrid Holzheid ${ }^{2}$ (D) and Christopher Heilmann ${ }^{2}$ \\ 1 Institute of Pre- and Protohistoric Archaeology, Kiel University, 24118 Kiel, Germany \\ 2 Institute of Geosciences, Kiel University, 24118 Kiel, Germany; astrid.holzheid@ifg.uni-kiel.de (A.H.); \\ christopher.heilmann@ifg.uni-kiel.de (C.H.) \\ * Correspondence: julia.menne@uni-hamburg.de
}

Received: 9 September 2020; Accepted: 16 October 2020; Published: 21 October 2020

\begin{abstract}
Archaeometric investigation of ancient pottery with regard to their material composites allows insights into the material structures, production techniques and manufacturing processes. The applied methods depend on the classification of the pottery: some finds should remain unchanged for conservation reasons, other finds are less valuable or more common. While the first group cannot be destroyed for material analyses and the choice of analytical methods is limited, the latter can be investigated using destructive methods and thus can widen the spectrum of possible devices. Multi-element analyses of portable energy-dispersive X-ray fluorescence spectrometry (portable XRF) have become important for archaeological research, as portable XRF provides a quick overview about the chemical composition of potteries and can be used in non-destructive as well as destructive ways in addition to conventional microscopic examination and petrographic thin sections. While most portable XRF analyses of solely fracture surfaces do not provide satisfying results, portable XRF analyses on pulverized samples are a cost-efficient and fast alternative to wavelength-dispersive XRF (WD-XRF). In comparison to $\mathrm{WD}-\mathrm{XRF}$, portable $\mathrm{XRF}$ on pulverized samples provides reliable concentration data $(\mathrm{K}, \mathrm{Fe}, \mathrm{Rb}, \mathrm{Ti}, \mathrm{V}, \mathrm{Y}, \mathrm{Zn}, \mathrm{Zr})$, but other elements need to be corrected. X-ray microtomography $(\mu \mathrm{CT})$ has proven to be a non-destructive technique to derive not only the porosity of ancient pottery but also to characterize temper components and non-plastic inclusions. Hence, the $\mu \mathrm{CT}$ technique has the potential to extract valuable information needed by archaeologists, for example, to deduce details about manufacturing.
\end{abstract}

Keywords: X-ray microtomography; portable XRF; WD-XRF; archaeometry; ceramic; Neolithic

\section{Introduction}

Multi-element analyses of recent decades have gained importance in archaeological and geoarchaeological research. Those analyses enable a fast acquisition of large data sets beyond complex laboratory analyses. Thus, it is possible to explore many different questions such as the provenance and use of raw materials, production techniques, interaction models of people and their objects, as well as settlement structures.

Research commonly agrees that portable energy-dispersive X-ray fluorescence spectrometry (portable XRF) provides sufficient and accurate results of chemical compositions needed for linking different assemblages of archaeological finds together. As the increasing number of ceramic studies using portable XRF shows, the potential and practical application of this method has expanded enormously in recent years [1-11]. However, the reliability of the chemical compositions solely gained 
from portable XRF is still debatable. Numerous independent studies have shown that the quality of the portable XRF results depends on the heterogeneity of the sample(s). The more homogeneous the matrix, the more reliable the measurements [1,12-16].

As a case study aiming to clarify the reliability of portable XRF analyses even further, we measured the elemental contents of the ceramics of megalithic tombs, belonging to the Funnelbeaker Westgroup in north-western Germany (dating ca. 3500-2750 BC). These graves have a high amount of ceramic in them and were used as graves for a long period. They also were frequented in a post-use phase of the Single grave culture.

Since investigations based on optical parameters (optical microscopy and thin-section petrography) were already conducted [17], quantitative measurements of a portable energy-dispersive (ed) XRF device (Niton XL3t900; Graduate School "Human Development in Landscapes" at Kiel University, Kiel, Germany) were compared to a conventional wavelength-dispersive XRF device (WD-XRF; Panalytical MagixPRO with sample changer PW 2540 VCR; Institute of Mineralogy, University Hamburg, Kiel, Germany) to determine the limits of applicability. In addition, the same fragments were examined with X-ray microtomography ( $\mu \mathrm{CT}$, SkyScan1172; Institute of Geosciences, Kiel University, Kiel, Germany). Two-dimensional (2D) and 3D images were constructed based on $\mu \mathrm{CT}$ scans to shed light on the material structure, e.g., to extract temper components as well as non-plastic inclusions and their related porosity non-destructively.

To conclude, the aim of this study is to evaluate the quality and limits of those measurement techniques and to put constraints on their reliability and applicability for archaeological interpretations of ceramic studies in order to draw, for example, conclusions about the origin and production technique of the finds.

\subsection{Main Aim and Question}

The following questions emerge from the interrelation of the analysis methods: As mentioned before, the percentage of portable XRF research on ceramics in archaeology has increased significantly since the early 2010s. The first application studies point out their possibilities and limitations [4,18-21]. Our aim is to investigate the practical applications regarding the position of the measurements on the sample, the measurement of powder and fractures in comparison, as well as the quality of the measurements after heating of the samples [22]. Falsification of the results by the ageing of the X-ray tube is a factor that should not be underestimated. Thus, we also studied how the maintenance of the software (and hardware) affects the results.

Material studies in archaeology often use the apparent cost-effective portable XRF measurement with lack of verification of measured values compared to WD-XRF. Which differences, regarding the element compositions, can be recognized between the conventional WD-XRF and the portable XRF? In order to answer this question, the same samples were measured as fresh fractions and as powder using both X-ray fluorescence methods.

A further aspect focuses on petrographic thin sections and non-destructive $\mu \mathrm{CT}$. Can the identified components of the temper in the thin sections be verified by $\mu \mathrm{CT}$ ? The surfaces of the fractures were reconstructed in order to define porosities and cavities. The question is whether in future the application of $\mu \mathrm{CT}$ can supplement or even replace thin sections.

\subsection{Archaeological Context of the Used Ceramics}

All samples of our study belong to megalithic graves of the administrative district of Emsland, Lower Saxony, Germany. The megalithic tombs in Emsland are part of the north-central European Funnelbeaker culture covering an absolute chronological period from about 3500 to 2750 BC [23,24].

The Emsland is characterized by the flat mountain range of Hümmling and is well known for its many megalithic tombs. Palynological studies on the local wet soils reveal the first traces of human settlement activities and impacts of agriculture, livestock breeding and thus an opening of the landscape from about $3500 \mathrm{BC}$ onwards [25-29]. The first urbanization of the landscape was 
followed shortly afterwards by the erection of the first megalithic tombs. A large number of grave goods exist in the megalithic tombs of the Funnelbeaker Westgroup, i.e., the region between the river Ijssel and the river Weser. In addition to the deposit of flint and rock artefacts as well as amber objects, the majority of grave goods are mostly pottery in various shapes and sizes. Over a period of several hundred years, hundreds of vessels were placed in the graves. Thus, the Funnelbeaker pottery offers a solid basis for interdisciplinary research due to its comparatively good preservation and large number of finds as well as its stylistic diversity. In total, 134 tombs are known in the Emsland, partly only from travel descriptions of the 19th century. Of these, 66 have been preserved completely or as remains $[17,30,31]$. Figure 1 summarizes the distribution of megalithic graves in the Emsland. The systematic investigation of this grave pottery began at the beginning of the 20th century with a number of excavations. Within the framework of the "Emsland Plan" in the 1950s, more excavations took place e.g., in Groß Berßen 3 to 5, 7, Emmeln 1 and 2, Lahn 4 [32-38] and Ostenwalde 1 [39,40].

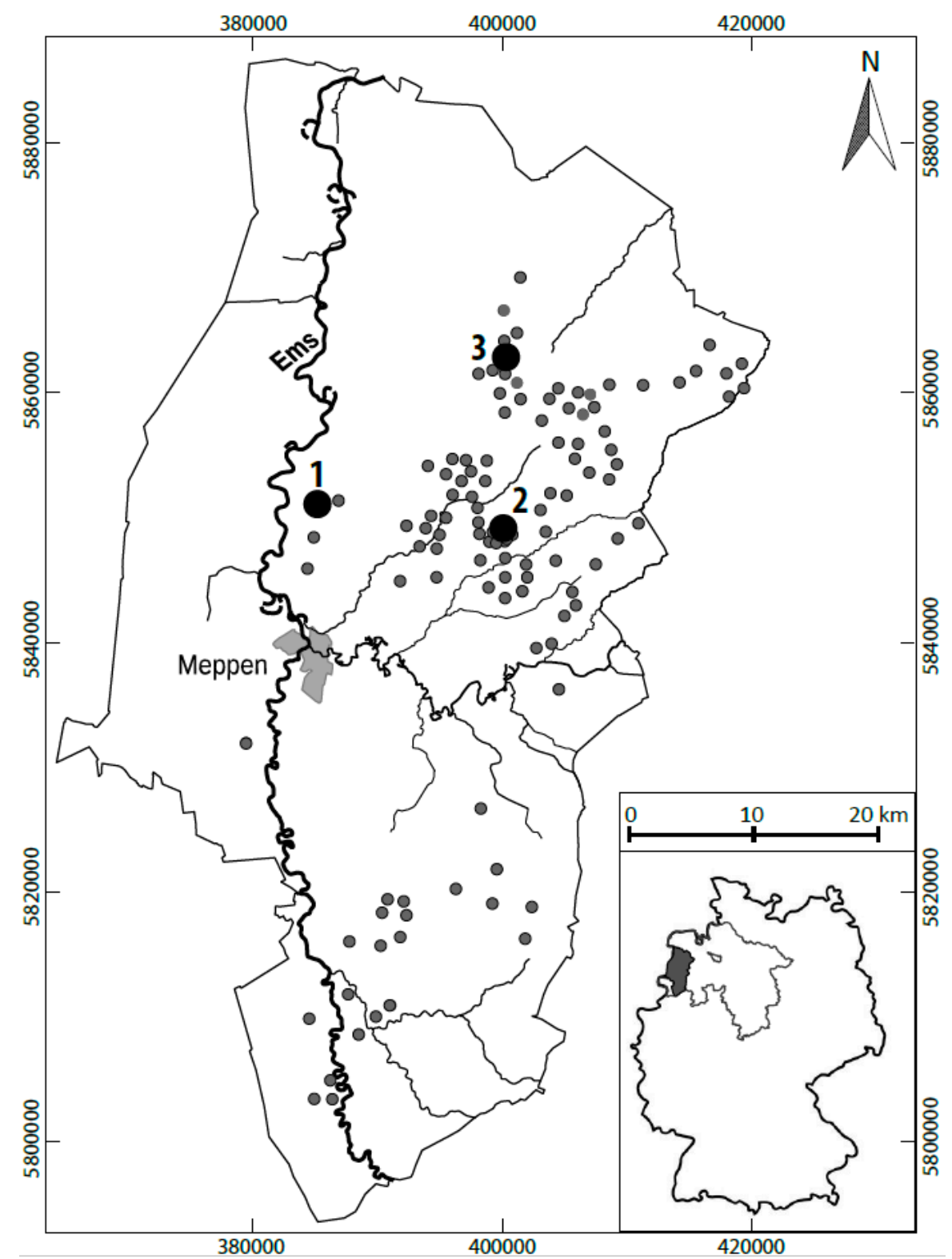

Figure 1. Distribution of megalithic graves in the study area, district Emsland, Lower Saxony, Germany. Grey dots $=$ megalithic grave, black dots = examined sites (1: Emmeln 2, E2; 2: Groß Berßen 7, GB7; 3: Werpeloh 43, WP43). See Table 1 for more details. 
The well-established typological studies mainly of the 2nd part of the 20th century are now supplemented by scientific analysis used by archaeologists starting primarily in the 2010s, allowing insights into social networks, landscape development and material studies of grave goods [41-47].

\section{Materials and Methods}

In total, 19 samples from three sites of megalithic graves in northwest Germany [17] were selected for a comparison of portable XRF, WD-XRF measurements, X-ray microtomography scans and thin sections (Table 1). Additionally, two reference samples named Standard I and Standard II were generated to verify the results. All measurements were conducted on the exact same samples to gain an exact comparison between the methods used.

Table 1. Ceramic samples of this study and allocation to the selected megalithic tombs Emmeln 2 (E2), Groß Berßen 7 (GB7) and Werpeloh 43 (WP43) of the district of Emsland (Lower Saxony, Germany), including information about the samples and employed analytical methods.

\begin{tabular}{|c|c|c|c|c|c|c|c|c|}
\hline No. & Sample & Site & Cate-Gory ${ }^{1}$ & $\begin{array}{c}\text { X-ray } \\
\text { Micro-Tomography }\end{array}$ & $\begin{array}{l}\text { Thin } \\
\text { Section } \\
\text { No. }^{2}\end{array}$ & $\begin{array}{c}\text { Portable } \\
\text { XRF } \\
\text { Fracture }\end{array}$ & $\begin{array}{c}\text { Portable } \\
\text { XRF } \\
\text { Powder }\end{array}$ & WD-XRF \\
\hline 1 & 20080021200009_2253 & WP43 & $4 / b$ & $\checkmark$ & & $\checkmark$ & $\checkmark$ & $\checkmark$ \\
\hline 2 & 20080015500007_2281 & WP43 & $5 / \mathrm{b}$ & $\checkmark$ & 360 & $\checkmark$ & $\checkmark$ & $\checkmark$ \\
\hline 3 & 20080027800005_0 & WP43 & $\mathrm{s}$ & $\checkmark$ & 362 & $\checkmark$ & $\checkmark$ & $\checkmark$ \\
\hline 4 & 20080024000005_125 & WP43 & $\mathrm{f}$ & $\checkmark$ & & $\checkmark$ & $\checkmark$ & $\checkmark$ \\
\hline 5 & 20080031400002_2325 & WP43 & $\mathrm{f}$ & $\checkmark$ & 358 & $\checkmark$ & $\checkmark$ & $\checkmark$ \\
\hline 6 & 20080118100021_603 & E2 & $3 / \mathrm{b}$ & $\checkmark$ & 369 & $\checkmark$ & $\checkmark$ & $\checkmark$ \\
\hline 7 & 20080020100025_1112 & E2 & $4 / \mathrm{b}$ & $\checkmark$ & & $\checkmark$ & $\checkmark$ & $\checkmark$ \\
\hline 8 & 20080020100013_796 & E2 & $4 / \mathrm{b}$ & $\checkmark$ & 370 & $\checkmark$ & $\checkmark$ & $\checkmark$ \\
\hline 9 & 20080107300006_1310 & E2 & $\mathrm{f}$ & $\checkmark$ & & $\checkmark$ & $\checkmark$ & $\checkmark$ \\
\hline 10 & 20080107300009_1138 & E2 & $\mathrm{f}$ & $\checkmark$ & 367 & $\checkmark$ & $\checkmark$ & $\checkmark$ \\
\hline 11 & 20080029600055_2221 & GB7 & $3 / \mathrm{b}$ & $\checkmark$ & & $\checkmark$ & $\checkmark$ & $\checkmark$ \\
\hline 12 & 20080029600009_2008 & GB7 & $5 / \mathrm{b}$ & $\checkmark$ & & $\checkmark$ & $\checkmark$ & $\checkmark$ \\
\hline 13 & 20080022500017_2106 & GB7 & c & $\checkmark$ & 364 & $\checkmark$ & $\checkmark$ & $\checkmark$ \\
\hline 14 & 20080011500010_2077 & GB7 & $\mathrm{f}$ & $\checkmark$ & & $\checkmark$ & $\checkmark$ & $\checkmark$ \\
\hline 15 & 20080022500016_2103 & GB7 & $\mathrm{f}$ & $\checkmark$ & & $\checkmark$ & $\checkmark$ & $\checkmark$ \\
\hline 16 & 20080020100013_769_ht & E2 & $4 / \mathrm{b}$ & & 370 & & $\checkmark$ & \\
\hline 17 & 20080015500007_2281_ht & WP43 & $5 / \mathrm{b}$ & & 360 & & $\checkmark$ & \\
\hline 18 & 20080027800005_0_ht & WP43 & $\mathrm{s}$ & & 362 & & $\checkmark$ & \\
\hline 19 & $20080012300012 \_2314$ & WP 43 & $\mathrm{~s}$ & $\checkmark$ & 361 & & & \\
\hline 20 & Standard I & & & $\checkmark$ & & & & \\
\hline 21 & Standard II & & & $\checkmark$ & & & & \\
\hline
\end{tabular}

\subsection{Optical Description: Macroscopic and Thin-Section Microscopy}

In general, ceramics consist of fired clay, temper and non-plastic material. Temper material can be sand, rock fragments, shell or bone remains or broken pottery (also called grog) to name a few. Non-plastic material is organic matter, e.g., plant fibers. Depending on the used temper and non-plastic materials and their quantities, the firing quality of the ceramic can be adjusted and shrinkage or cracking of the pottery during drying and firing can be prevented. The study of temper and non-plastic materials provides constraints on the manufacturing technique and might even allow identification of the place of manufacture. Two options exist for optical description: macroscopic descriptions and thin-section microscopy.

Macroscopic descriptions are non-destructive. Hand lenses used for field geology (low power (10x) magnification) or a high-resolution binocular loupe allow easy identification of phases up to $\sim 2 \mathrm{~mm}$ in size, but limitations exist for artifacts with weathered rinds. Thin section microscopy is an abrasive method. Thin sections of the ceramics are prepared by cutting, and polishing a slice of ceramic mounted on a glass slide to a thickness of $0.03 \mathrm{~mm}$. As fresh cut faces are produced and 
polished, weathered rinds are less common. Not only is identification of minerals that are only $0.1 \mathrm{~mm}$ in size easily possible, crushed rocks (rock fragments) can be classified and textural relationships of the present temper materials can be derived. Thin sections are by far the most common use of optical mineralogy in geoscience, but less frequently used in archaeology.

\subsection{Analytical Methods}

\subsubsection{Portable Energy-Dispersive X-Ray Fluorescence Spectrometry (Portable XRF)}

The portable XRF (portable energy dispersive X-ray fluorescence spectrometry) as an energy-dispersive handheld X-ray fluorescence technology is often used in archaeology [48-51]. It is non-destructive and reliable, requires no, or very little, sample preparation and is suitable for solid and powdered samples. The advantage of this method regarding the usage in archaeology is that either no sample or only a small part of the sample has to be destroyed (for producing powder) to determine chemical compositions. As results are provided within a few minutes, analyses of exhibits in museums or in the field are easy to obtain.

Even if samples are allowed to be pulverized, measurements in archaeology are often carried out only on fresh fracture surfaces. Handheld XRF beam spot size usually is $10 \mathrm{~mm}$ in diameter and can be collimated down to $3 \mathrm{~mm}$ X-ray beam. Measurements on fresh fracture surfaces of pottery sherds with temper phases of $5 \mathrm{~mm}$ and larger will thus not provide reliable average chemical composition as the heterogeneity is larger than the area exposed to the X-ray beam [12,20].

Some of the sherds in the present study are heterogeneous and contain coarse inclusions (mineral grains, fragments of rocks, bones and/or even pottery sherds) with sizes of up to $2 \mathrm{~mm}$. To judge if measurements on fresh fracture surfaces might still provide suitable average chemical compositions of the entire sherds, not only were those fracture surfaces measured, aliquots of the sherds were also ground to powder. Aliquots of those powders (1) were transferred into plastic containers (outer diameter: $29 \mathrm{~mm}$; inner diameter: $18 \mathrm{~mm}$; height: $25 \mathrm{~mm}$ ), sealed with a special foil (polypropylene XRF foil TF-240-255 (4.0 $\mu \mathrm{m})$ by FLUXANA) and directly analyzed by portable XRF, (2) were at first heated to $1050{ }^{\circ} \mathrm{C}$ for $3 \mathrm{~h}$ to transfer all elements in their highest oxidation state $[8,22]$, transferred into containers, sealed and subsequent analyzed by portable XRF, or (3) were processed into glass disks by fusion and analyzed by wavelength dispersive X-ray fluorescence spectrometry (WD-XRF; see below for more details). This even allowed comparison of portable XRF and WD-XRF.

In the present study, the NITON XL3t instrument of the 900 GOLDD series (ThermoFisher Scientific, Waltham, MA, USA) was used. The instrument was operated in the company's pre-set mining mode, which measures 35 main and trace elements using 4 filters. Total duration of measurement was $300 \mathrm{~s}$ (main filter: $40 \mathrm{kV}, 50 \mathrm{~mA}, 60 \mathrm{~s}$; high filter: $50 \mathrm{kV}, 40 \mathrm{~mA}, 60 \mathrm{~s}$; low filter: $20 \mathrm{kV}, 100 \mathrm{~mA}, 60 \mathrm{~s}$; light filter: $6 \mathrm{kV}, 100 \mathrm{~mA}, 120 \mathrm{~s}$ ). The analytical range was from magnesium to uranium with detection limits of main elements of $\sim 0.0025 \mathrm{wt} . \%$ and trace elements of 3-600 ppm (detection limits provided by the manufacturer for a $\mathrm{SiO}_{2}$ matrix in mining mode with a duration of measurements of $60 \mathrm{~s} /$ filter).

All measurements were performed under constant helium flow in a laboratory with standard state conditions and a relative humidity of $40-50 \%$. The waiting time between individual measurements was $60 \mathrm{~s}$ to ensure restoration of helium atmosphere surrounding the sample. Accuracy of measurements was regularly tested by the double measuring loess standard GBW07411 and metal standard IARM $35 \mathrm{HN}$ as unknown samples. On each fracture surface three optical homogeneous areas were measured. Powders were measured 4 to 9 times to check for precision (as also recommended by [3,12,52]). After each of those measurements, the containers were rotated to remix the powder and to ensure a homogenous mixture of the powder. Average values were calculated based on the individual analyses.

Our study revealed that the measuring accuracy depends not only on the calibration of the device but also on the age of the X-ray tube. After about 4 to 5 years the measuring quality decreases as the age of the X-ray tube causes less precise detection of some elements. Standard GBW04711 (soil standard-loess, Institute of Geophysical and Geochemical Exploration, Chinese Academy of 
Geological Sciences) corresponds approximately to the chemical composition of the tomb ceramics. The standard was always measured as an unknown sample before and after each set of analyses as well as during one set of analyses.

In addition, we compiled former and recent analyses of GBW04711 as unknown samples to determine any changes caused by the instrument and how those affect the results. The instrument of the Graduate School at Kiel University, Germany, was bought in 2010, and underwent maintenance only in November 2014 and January 2019. Table 2 lists literature values of GBW04711 and element concentrations of GBW04711 measured as unknown samples. Four measurement series are compared: (I) measurement series after maintenance in 2014; (II) measurement series before maintenance in 2019; (III) measurement series after maintenance in 2019 with old X-ray tube; (IV) measurement series with new X-ray tube in 2019.

Table 2. Element concentrations of GBW04711 (literature values) and measured as unknown sample.

\begin{tabular}{|c|c|c|c|c|c|}
\hline \multirow[b]{2}{*}{ Element } & \multicolumn{5}{|c|}{ Standard GBW07411 } \\
\hline & $\begin{array}{c}\text { Literature } \\
\text { [53] }\end{array}$ & $\begin{array}{c}\text { I } \\
\text { After Maintenance } \\
2014 \\
\text { Mean } \pm \text { Standard } \\
\text { Deviation }\end{array}$ & $\begin{array}{c}\text { II } \\
\text { Before Maintenance } \\
2019 \\
\text { Mean } \pm \text { Standard } \\
\text { Deviation }\end{array}$ & $\begin{array}{c}\text { III } \\
\text { After Maintenance } \\
2019 \\
\text { Mean } \pm \text { Standard } \\
\text { Deviation }\end{array}$ & $\begin{array}{c}\text { IV } \\
\text { With New X-ray } \\
\text { Tube in } 2019^{1} \\
\text { Mean } \pm \text { Standard } \\
\text { Deviation }\end{array}$ \\
\hline Ce [ppm] & 66.3 & $68 \pm 5$ & $91 \pm 8$ & $90 \pm 4$ & $88 \pm 5$ \\
\hline $\mathrm{Ba}[\mathrm{ppm}]$ & 550 & $668 \pm 12$ & $692 \pm 24$ & $766 \pm 21$ & $757 \pm 27$ \\
\hline Sn [ppm] & 64.3 & $31 \pm 2$ & $35 \pm 2$ & $70 \pm 2$ & $70 \pm 3$ \\
\hline $\mathrm{Cd}[\mathrm{ppm}]$ & 28.2 & $28 \pm 3$ & $28 \pm 2$ & $34 \pm 3$ & $33 \pm 3$ \\
\hline $\mathrm{Nb}[p p m]$ & 15.1 & $11 \pm 1$ & $18 \pm 2$ & $13 \pm 1$ & $13 \pm 1$ \\
\hline $\mathrm{Zr}[\mathrm{ppm}]$ & 192 & $184 \pm 2$ & $182 \pm 2$ & $191 \pm 3$ & $190 \pm 3$ \\
\hline $\mathrm{Y}[\mathrm{ppm}]$ & 24.2 & $25 \pm 2$ & $25 \pm 2$ & $24 \pm 1$ & $24 \pm 1$ \\
\hline Sr [ppm] & 130 & $129 \pm 1$ & $86 \pm 1$ & $128 \pm 1$ & $128 \pm 1$ \\
\hline $\mathrm{Rb}[\mathrm{ppm}]$ & 111 & $114 \pm 2$ & $115 \pm 1$ & $118 \pm 2$ & $118 \pm 1$ \\
\hline As [ppm] & 205 & $169 \pm 8$ & $162 \pm 10$ & $150 \pm 9$ & $159 \pm 12$ \\
\hline $\mathrm{Pb}[\mathrm{ppm}]$ & 2700 & $2865 \pm 29$ & $2677 \pm 16$ & $2707 \pm 10$ & $2708 \pm 10$ \\
\hline $\mathrm{Zn}[\mathrm{ppm}]$ & 3800 & $3826 \pm 3$ & $3857 \pm 10$ & $3812 \pm 19$ & $3810 \pm 17$ \\
\hline $\mathrm{Cu}[\mathrm{ppm}]$ & 65.4 & $50 \pm 6$ & $42 \pm 3$ & $62 \pm 4$ & $60 \pm 6$ \\
\hline $\mathrm{Fe}[\mathrm{wt} . \%]$ & 5.60 & $5.70 \pm 0.04$ & $5.54 \pm 0.01$ & $5.57 \pm 0.01$ & $5.57 \pm 0.01$ \\
\hline Mn [wt.\%] & 0.97 & $0.96 \pm 0.01$ & $0.92 \pm 0.01$ & $0.98 \pm 0.01$ & $0.98 \pm 0.01$ \\
\hline Cr [ppm] & 59.6 & $113 \pm 20$ & $117 \pm 10$ & $147 \pm 13$ & $146 \pm 12$ \\
\hline $\mathrm{V}$ [ppm] & 88.5 & $94.2 \pm 12$ & $90 \pm 12$ & $93 \pm 10$ & $95 \pm 25$ \\
\hline $\mathrm{Ti}$ [ppm] & 4100 & $3855 \pm 167$ & $3624 \pm 185$ & $4474 \pm 155$ & $4483 \pm 170$ \\
\hline Ca [wt.\%] & 3.1 & $3.1 \pm 0.04$ & $3.1 \pm 0.02$ & $3.1 \pm 0.01$ & $3.1 \pm 0.02$ \\
\hline K [wt.\%] & 1.7 & $1.7 \pm 0.02$ & $1.7 \pm 0.03$ & $1.7 \pm 0.01$ & $1.7 \pm 0.01$ \\
\hline Al [wt.\%] & 6.4 & $3.2 \pm 0.38$ & $5.9 \pm 0.51$ & $6.1 \pm 0.16$ & $5.9 \pm 0.41$ \\
\hline $\mathrm{P}$ [ppm] & 1400 & $3227 \pm 134$ & $1155 \pm 163$ & $1179 \pm 49.3$ & $1139 \pm 77.4$ \\
\hline Si [wt.\%] & 22 & $15 \pm 0.95$ & $20 \pm 1.44$ & $23 \pm 0.47$ & $22 \pm 0.94$ \\
\hline $\operatorname{Mg}$ [wt.\%] & 2.20 & $0.61 \pm 0.14$ & $1.86 \pm 0.16$ & $1.88 \pm 0.06$ & $1.88 \pm 0.16$ \\
\hline bal [ppm] & $\mathrm{n} / \mathrm{a}^{2}$ & 680,827 & 599,993 & 563,506 & 572,249 \\
\hline
\end{tabular}

Detection limits as provided by the manufacturer are $\sim 0.0025 \mathrm{wt} . \%$ for major elements and 3-600 ppm for minor and trace elements. In this study measured mean values for major elements and standard deviations are with precisions of $0.01 \mathrm{wt} . \%$ and less. For minor and trace elements both mean values and standard deviations are provided with maximum precisions of $1 \mathrm{ppm}$; the portable XRF device additionally calculates the amount of unmeasured residues (listed as balance "bal" in the table); ${ }^{1}$ : kindly provided by M. Talma, Institute of Pre- and Protohistoric Archaeology, Kiel University; ${ }^{2}$ : not applicable.

Table 2 clearly demonstrates the dependence of the accuracy of some elements on the age of the $\mathrm{X}$-ray tube (e.g., $\mathrm{Ce}, \mathrm{Ba}, \mathrm{Mn}, \mathrm{Ti}$ ), while others are independent (e.g., $\mathrm{Pb}, \mathrm{Zn}, \mathrm{Fe}, \mathrm{Ca}, \mathrm{K}$ ) or can be restored by the maintenance (e.g., $\mathrm{Zr}, \mathrm{Sr}, \mathrm{Si}$ ). Caution has to be taken for elements close to the detection limits, such as $\mathrm{Nb}$, As, or Cr. Elements' accuracy that can be restored by the maintenance might be corrected prior to maintenance using correction factors. 


\subsubsection{Wavelength Dispersive X-ray Fluorescence Spectrometry (WD-XRF)}

Wavelength-dispersive $\mathrm{X}$-ray fluorescence spectrometry (WD-XRF) is a destructive and standard technique to determine bulk analyses. The higher resolution of WD-XRF compared to portable XRF provides advantages in terms of reduced spectral overlap. Complex samples can be more accurately characterized. In addition, with high-resolution backgrounds reduced, WD-XRF provides improved detection limits and sensitivity. Although samples can be measured as powder pellets as well as solid glass disks, usually glass disks are used in geoscientific applications. The glass disks are prepared using a fusion technique as this technique comprises of the reaction at a high temperature between a molten lithium borate flux and the specimen in order to develop a homogeneous molten glass that is finally cooled without crystallizing to produce an amorphous homogeneous solid glass disk.

The sherds were coarsely crushed after completion of X-ray microtomography (see below for more details) and ground to fine powder in an automatic powder mill. Further processing of the fused glass disks and subsequent WD-XRF measurements were conducted at the Institute of Mineralogy and Petrography, University Hamburg.

After determination of loss of ignition at $1050{ }^{\circ} \mathrm{C}, 600 \mathrm{mg}$ of the remaining sample powder was thoroughly mixed with $3600 \mathrm{mg}$ lithium tetraborate $\left(\mathrm{Li}_{2} \mathrm{~B}_{4} \mathrm{O}_{7}\right)$ and glass disks were prepared using the fusion technique. The WD-XRF measurements were performed using the Panalytical MagixPRO WD-XRF device with sample changer PW 2540 VCR. The analytical range was from sodium to uranium with detection limits of main elements $\mathrm{Na}$ and $\mathrm{Mg}$ of $0.01 \mathrm{wt} . \%$, others less than $0.01 \mathrm{wt} . \%$ and trace elements Ce of 20 ppm, Ba and Nd 10 ppm, and others less than 5 ppm.

\subsubsection{X-ray Microtomography $(\mu \mathrm{CT})$}

$\mathrm{X}$-ray microtomography is a non-destructive technique that provides information of realistic 2D and $3 \mathrm{D}$ geometries of samples. Continuous image volume inspections can be undertaken by computer-aided morphometry and quantitative image analysis. It has been deployed for the characterization of true 3D microfabrics in respect to volume fractions, geometric surface, and size distribution of the fabric elements, including pores and porosity determination [54]. Because X-ray microtomography is a non-destructive technique it has a decisive advantage over XRF and thin-section petrography when investigating ancient pottery. Volume fractions of temper phases and non-plastic inclusions can be characterized and 3D visible orientation of pores can be detected and classified. This allows, for example, conclusions in respect to the manufacturing procedure of the pottery.

The X-ray microtomography scans were undertaken using the SkyScan1172 system (Bruker-SkyScan, Billerica, MA, USA). The SkyScan1172 is a tabletop unit that allows high-resolution scans. It is suitable for samples with diameters of up to $35 \mathrm{~mm}$ and a height of $18 \mathrm{~mm}$. Oversize scans, corresponding to three individual measurements, allow scanning of samples of up to $55 \mathrm{~mm}$ height. All samples were scanned with a beam energy of $100 \mathrm{kV}$, a current (flux) of $100 \mu \mathrm{A}$ and, depending on the sample, aluminum or aluminum-copper filters. A $360^{\circ}$ rotation with a step size of $0.5^{\circ}$ and medium resolution was employed in the detector, resulting in a resolution of $17.3 \mu \mathrm{m}$ per pixel. The SkyScan software NRecon (version 1.7.3.2, Bruker-SkyScan, Billerica, MA, USA) was used for reconstruction of the spatial information of the scanned ceramics. For each sample, approximately 1000 stacked layer imageswere created, summing up to 3000 stacked layered images in oversized scan mode. Each layer image consists of isometric voxels (volumetric pixels) whose sizes depend on the detector resolution. Thus, the stacked images have volumetric information. Information about various phases that result in a different degree of absorption of $\mathrm{X}$-rays is stored in grey values and decoded into black and white images during evaluation. Segmentation and binarization, i.e., the assignment of materials and gray values, image analysis and visualization, was undertaken with the SkyScan software CTAn and CTVol.

Proper characterization of pore volumes (porosities) and temper materials could be used to put constraints on the manufacturing procedure of the objects. This means that the porosities or air inclusions have to be quantified in order to define the ratio of matrix, temper particles plus non-plastic inclusions and cavities. 
For this purpose, a quantitative test was conducted on ink filler balls. These have a standardized diameter ( $2.5 \pm 0.1 \mathrm{~mm}$ glass balls) and were filled into a plastic container of known volume. This allows precise calculation of the spaces or cavities as artificial porosities. An X-ray microtomography scan was performed on the ink filler balls while placed in the container. Figure 2a depicts the absorbed $X$-rays and Figure $2 b$ is the reconstructed $3 \mathrm{D}$ view. All ink filler balls were made of glass, except one ball that was made of plastic and was easily recognizable in Figure $2 b$ as a darker sphere due to the smaller density of plastic compared to glass.
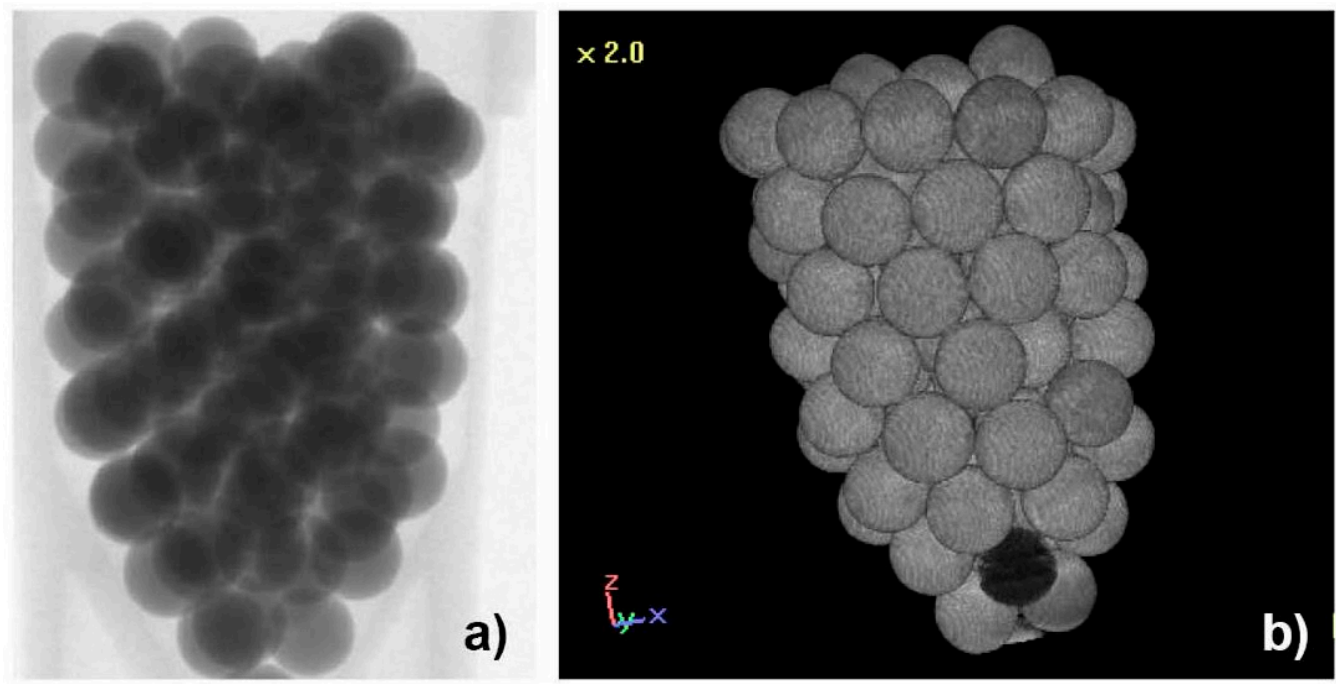

Figure 2. (a) X-ray-microtomography scan of ink filler pens; (b) 3D view: the dark sphere is made of plastic, all the others of glass.

After the scan a so-called region of interest (ROI) was generated around the ink filler balls and a $3 \mathrm{D}$ analysis was performed using the software CTAn. For manual calculation, the total volume of the balls was calculated by their number and diameter. The total volume of all balls ranged between 702 and $893 \mathrm{~mm}^{3}$ by taking into account the diameter's tolerance of $0.1 \mathrm{~mm}$. Subtracting the total volume of all balls from the ROI volume gave the pore space (see Table 3). The software-based calculation of pore space $(61 \%)$ was bracketed by the manually calculated values taking into account the varying ball diameters $(64 \pm 4 \%)$. Thus, porosities of the studied ceramics could be derived by the SkyScan software CTAn.

Table 3. Range of pore space in container with 97 ink filler balls considering the tolerance of the diameter $(2.5 \pm 0.1 \mathrm{~mm})$.

\begin{tabular}{ccccc}
\hline Ink Filler Ball Diameters & Volume of One Ball & Volume of All Balls & Volume of Pore Space ${ }^{1}$ & Pore Space [\%] \\
\hline $2.4 \mathrm{~mm}$ (minimum) & $7.2 \mathrm{~mm}^{3}$ & $702 \mathrm{~mm}^{3}$ & $1513 \mathrm{~mm}^{3}$ & 68 \\
$2.5 \mathrm{~mm}$ (average) & $8.3 \mathrm{~mm}^{3}$ & $794 \mathrm{~mm}^{3}$ & $1421 \mathrm{~mm}^{3}$ & 64 \\
$2.6 \mathrm{~mm}$ (maximum) & $9.2 \mathrm{~mm}^{3}$ & $893 \mathrm{~mm}^{3}$ & $1322 \mathrm{~mm}^{3}$ & 60 \\
\hline
\end{tabular}

${ }^{1}$ Volume of pore space in container with $2215 \mathrm{~mm}^{3}$ (see text for more details).

In order to not only determine the porosity in a ceramic sample but also to determine possible components of the temper and non-plastic inclusions, two reference standards were manufactured and analysed by X-ray microtomography. Both reference standards consisted of a clay matrix with either temper material or temper material and non-plastic inclusions, which are also present in neolithic samples in approximately equal quantities. Standard I (Figure 3) included the following components: clay $10.012 \mathrm{~g}$, sand $1.003 \mathrm{~g}$, feldspar $0.507 \mathrm{~g}$, magnetite $0.028 \mathrm{~g}$, biotite $0.101 \mathrm{~g}$, hornblende $0.104 \mathrm{~g}$, calcite $0.197 \mathrm{~g}$, bone $0.088 \mathrm{~g}$, tooth fragment $0.086 \mathrm{~g}$, neolithic ceramic $0.069 \mathrm{~g}$. The total volume of Standard I was $5561 \mathrm{~mm}^{3}$. A volume of $199 \mathrm{~mm}^{3}$ was accounted for by the temper components 
(biotite, hornblende, bone, calcite, tooth). In Standard II (Figure 4), mainly organic material was added: straw, culm/husks, barley grains, but also pottery fragments, tooth fragments. The aim was to identify the components in a reference sample, which could also be found in the original samples either as impressions or fragments.
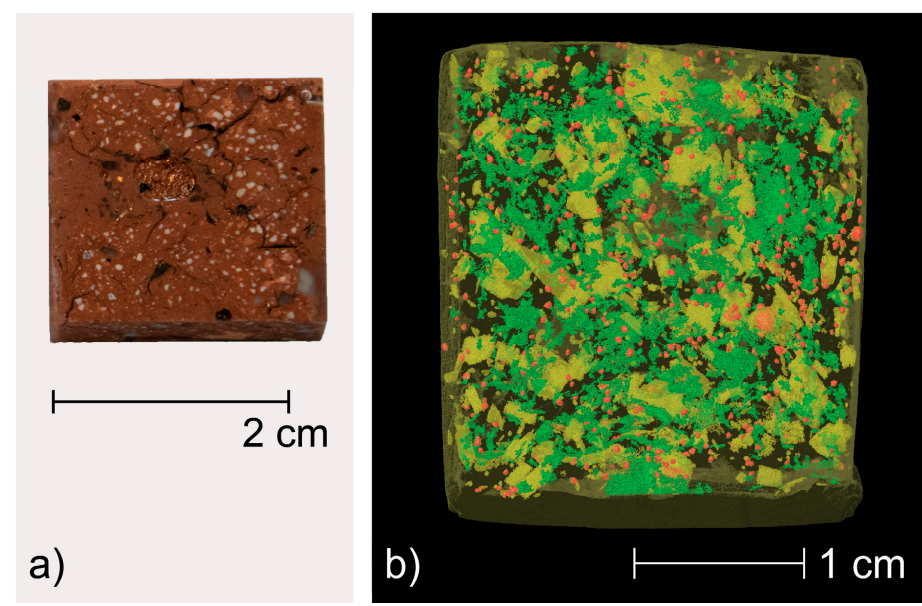

Figure 3. Standard I (a) impregnated with epoxy and polished; (b) X-ray microtomography scan (top view), visualized are only pores (green), heavy minerals, mainly magnetite (red), and some other minerals, i.e., feldspar/biotite/calcite (yellow). Please note the visualized components, including pores, appear inside the standard. The scan does not depict the components present at the outer surface of the standard.

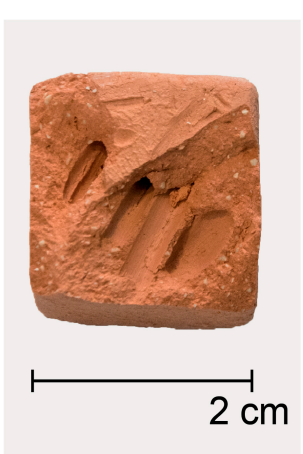

a)
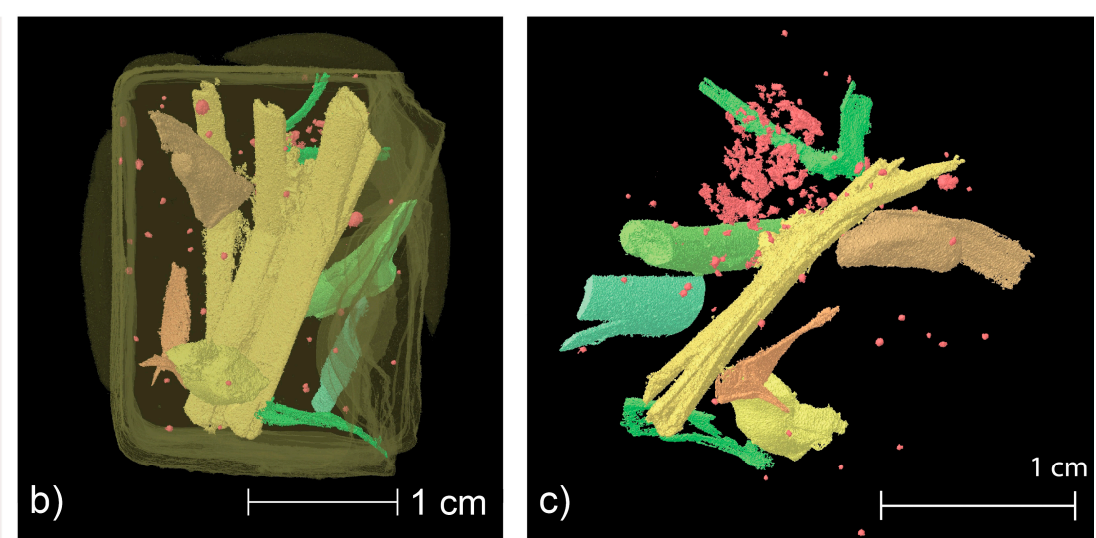

Figure 4. Standard II with organic components (a) impregnated with epoxy; (b) X-ray microtomography scan (top view); (c) detailed x-ray microtomography scan; visible phases: straw (yellow), heavy minerals, mainly magnetite (red), culm (green), hasks (turquoise), barley grains (beige), tooth fragment (dark brown).

Pores as well as temper components or non-plastic inclusions could be easily identified in both standards. Even in Standard II with its organic components, the individual objects were clearly visible (Figure $4 b, c)$. Based on the experience with the standards and phases therein, comparable components of temper and non-plastic inclusions in real neolithic samples could be satisfactorily identified by X-ray microtomography.

\section{Comparison of Results Derived by Various Methods}

\subsection{Macroscopic and Microscopic Observation}

The optical observations are summarized in Table 4. Descriptions can be either macroscopic, i.e., inspection of the sherds' surface and/or fractured surface, or by thin-section microscopy [17]. 
Table 4. Optical description of the ceramic samples from the study from the selected megalithic tombs.

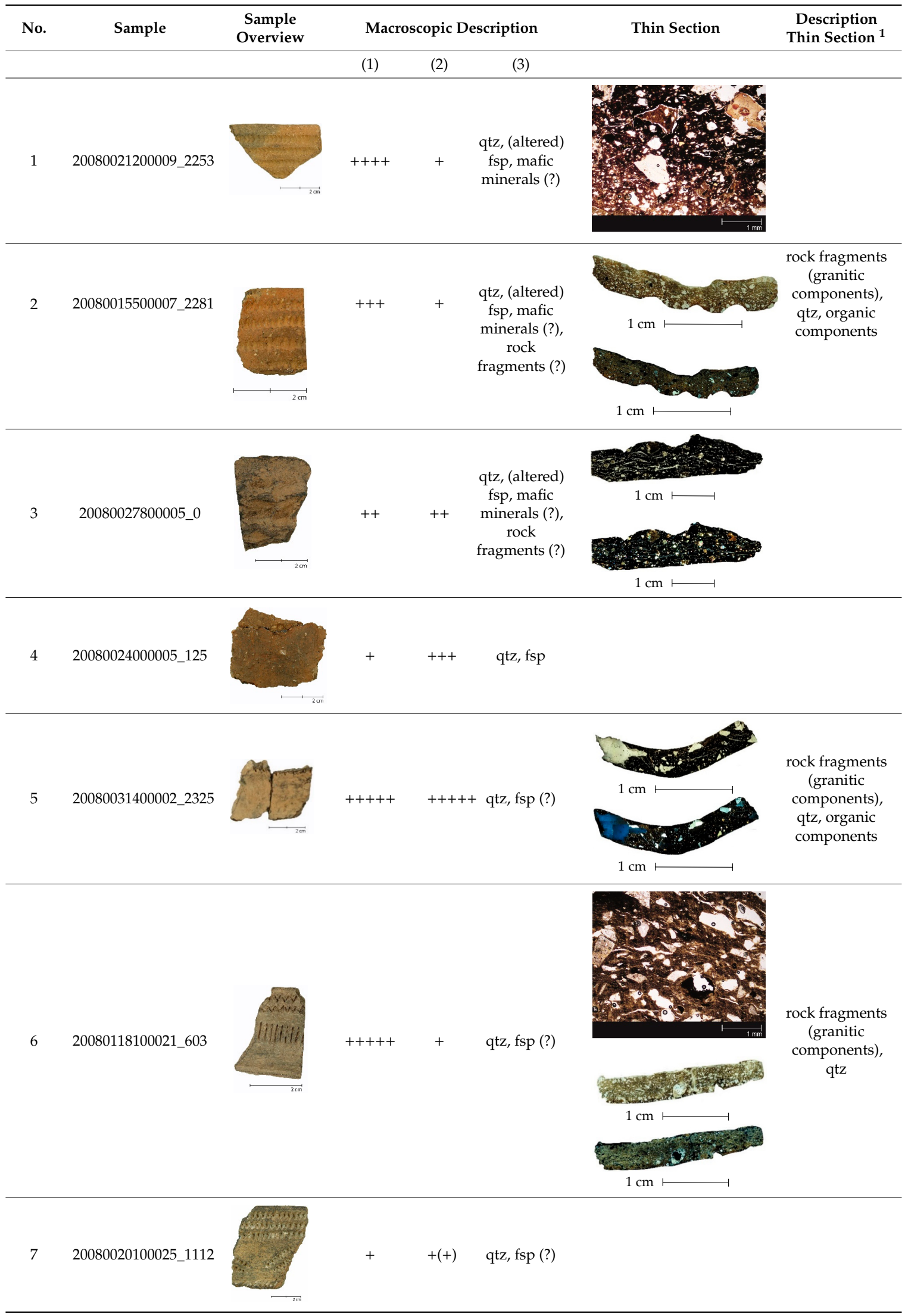


Table 4. Cont.

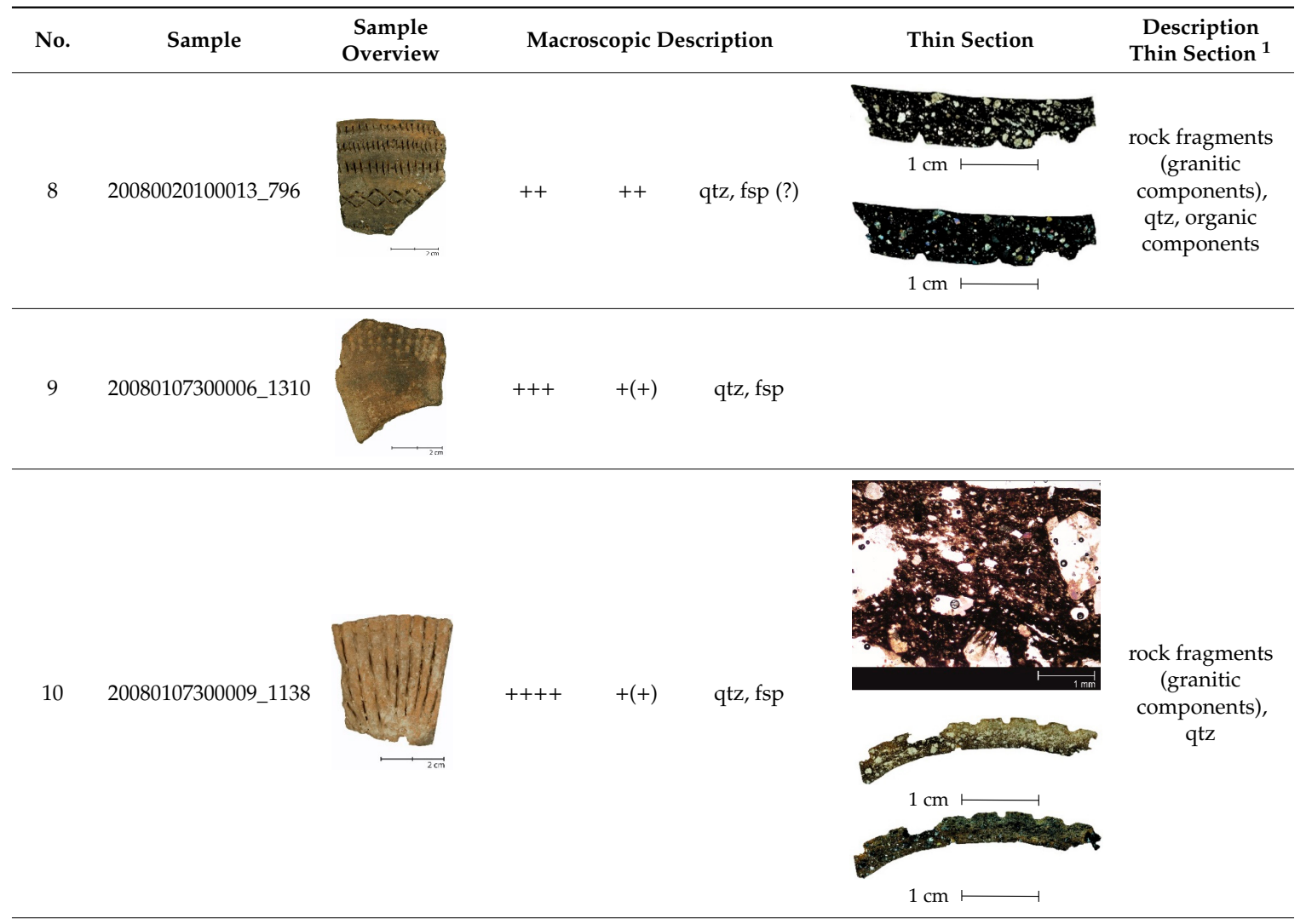

13 20080022500017_2106

\begin{tabular}{|c|c|c|c|c|}
\hline 14 & 20080011500010_2077 & + & +++ & qtz, fsp (?) \\
\hline 15 & 20080022500016_2103 & +++++ & ++ & $\begin{array}{l}\text { qtz, fsp (?) } \\
\text { (very small } \\
\text { frag-ments) }\end{array}$ \\
\hline
\end{tabular}

\footnotetext{
${ }^{1}$ Macroscopic descriptions: (1) relative amount of matrix to temper phases: +++++ (sample has the max of matrix of the group) $\ldots+$ + (min of group); (2) larger/smaller mineral (other) fragments in matrix: +++++ . + +; (3) Macroscopic identifiable mineral fragments [17].
} 
The limitations of macroscopic observation of the surface are weathered rinds and adhered dirt. Robust statements regarding clay and temper material are barely possible; but ornament and decoration features can be identified.

Fractured surfaces provided at first glance impressions of used clay and temper of the ceramics, visible as matrix and fragments inside the matrix. In addition, different mineral and rock fragments could be seen, although minerals like e.g., quartz and feldspar were not easy to distinguish and the portion of feldspar might be overestimated. Further identification of rock fragments was limited by magnification of hand lenses and binocular loupe.

More detailed observation was possible by thin section microscopy albeit this being an abrasive method. Not only inorganic temper phases could be identified (i.e., mineral phases and rock fragments, including rock determination), also organic temper components could be detected. However, some experience was needed to distinguish various mineral phases, as more than solely quartz was most likely present as temper in addition to rock fragments and organic components.

\subsection{Chemical Compositions (Portable XRF vs. WD-XRF)}

Chemical compositions of identical sherds measured either by WD-XRF or by portable XRF are compared in Figure 5. The dashed lines correlate WD-XRF results with portable XRF values of the same samples. Perfect agreement between WD-XRF and portable XRF exists for those measurements that fall on the solid line, i.e., 1:1 correlation line. The symbols visualize the different portable XRF measurements. To reiterate, WD-XRF measurements were conducted on fused glass disks. Aliquots of the powder used to prepare the glass disks were measured by portable XRF (dark grey squares). During fused glass disk preparation elements transfer in their highest oxidation state. Thus, additional aliquots of the powder were heated to $1050^{\circ} \mathrm{C}$ for $3 \mathrm{~h}$ prior to portable XRF measurements to test for any influence on XRF results if elements were existent in their highest oxidation state (open squares). As portable $\mathrm{XRF}$ are often used as a non-destructive technique in archaeology by analyzing fracture surfaces, the present fracture surfaces of the sherds were measured before grounding the sherds to powder for further processing (grey diamonds).

The following observations can be made:

1. Potassium, $\mathrm{Rb}, \mathrm{Ti}, \mathrm{V}, \mathrm{Y}, \mathrm{Zn}$, and $\mathrm{Zr}$ contents agreed well independent of technique used (WD-XRF and portable XRF) and portable XRF measurements on powder, heated powder or break planes.

2. Portable XRF measurements resulted in slightly higher Fe concentration compared to WD-XRF, but measurements on powder, heated powder or break planes agreed well.

3. Portable XRF measurements led to Cr values that were distinctly higher compared to WD-XRF, but again measurements on powder, heated powder or break planes agreed well.

4. Aluminium, $\mathrm{Ca}, \mathrm{Mg}, \mathrm{Si}, \mathrm{P}$, and $\mathrm{Sr}$ measured by p-ed XRF were lower compared to WD-XRF by element-specific factors. Agreement existed between powder and heated powder measurements, but measurements of break planes disagreed with powder measurements.

5. Niobium did not show an off-set that could be clearly related to over- or underestimated values. This might be due to the fact that $\mathrm{Nb}$-contents were close to detection limits. Agreement existed again between powder and heated powder measurements, but measurements of break planes provided random contents of the respective elements.

6. With the exception of the 3 elements $(\mathrm{Al}, \mathrm{Cr}$, and $\mathrm{Si})$, the quantity of all elements measured with the portable XRF device could be corrected by multiplying the results by the relevant coefficients from the regression equations. 

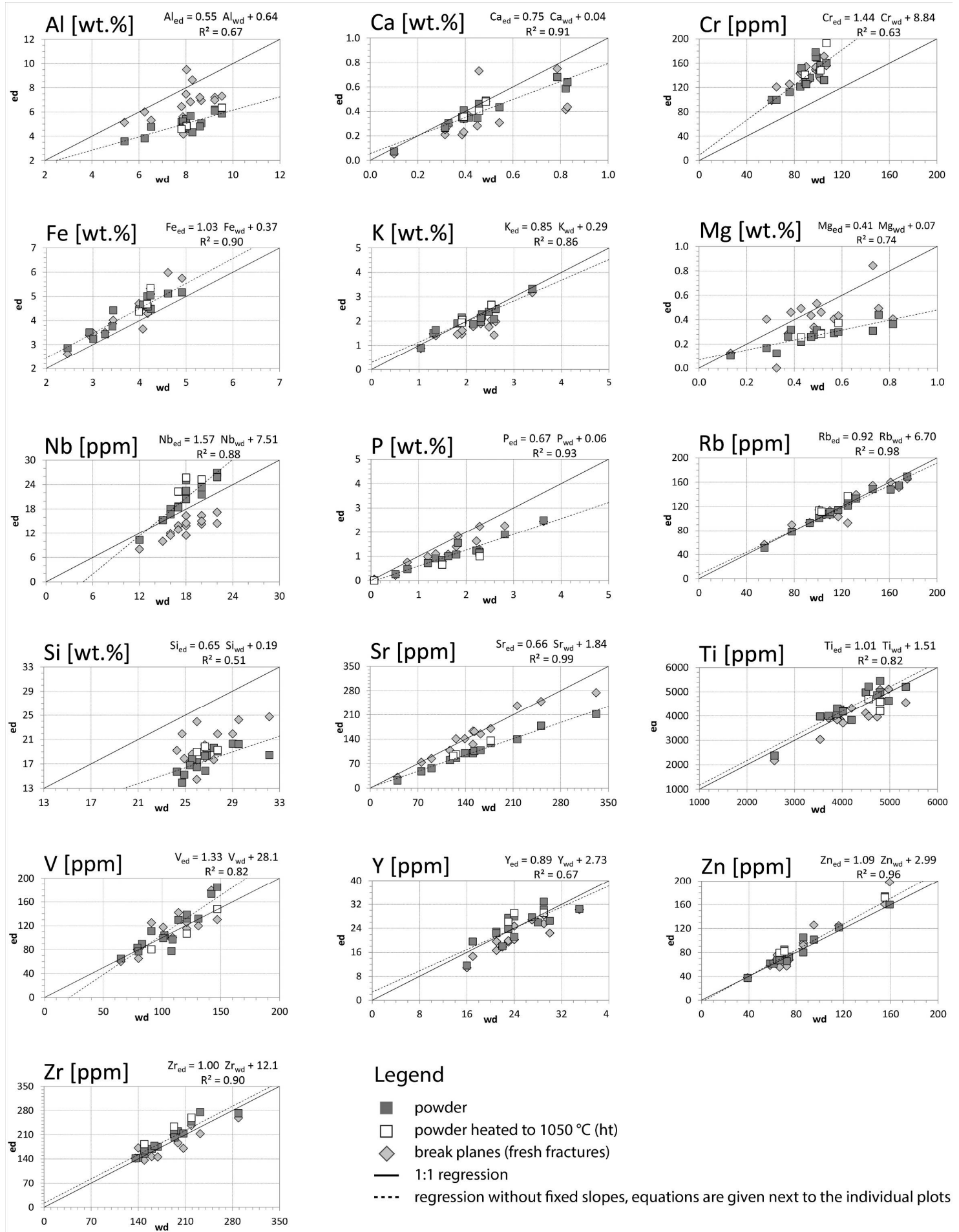

Figure 5. Comparison of portable XRF and WD-XRF measurements. All chemical data are available as a supplementary file (Table S1).

The limited reliability of the chemical analyses by applying the technique to fracture surfaces [55] was proved true. Measurements of powders provided satisfying data with regard to accuracy and precision for $\mathrm{K}, \mathrm{Fe}, \mathrm{Rb}, \mathrm{Ti}, \mathrm{V}, \mathrm{Y}, \mathrm{Zn}$, and $\mathrm{Zr}$. Iron revealed slightly higher contents in measured powder, but still acceptable values compared to WD-XRF measurements. We recommend correction for powder measurements to derive reliable concentrations for all elements except $\mathrm{K}, \mathrm{Rb}, \mathrm{Ti}, \mathrm{V}, \mathrm{Y}, \mathrm{Zn}$, and $\mathrm{Zr}$, as portable XRF measurements of those elements agreed well with WD-XRF measurements. However, 
the values of single elements in different sherds measured with an identical and routinely calibrated portable XRF device could be easily compared and grouping of sets of sherds based on their chemical bulk compositions was possible. In addition, publishing the analysis of reference materials along with the results obtained from the samples would provide all necessary information to evaluate possible deviations in the measurements, regardless of the technique used.

\subsection{Characterisation of Components and Porosities by 2D and 3D Sections}

Figure 6 shows examples of the comparison of various temper components and non-plastic inclusions in two neolithic samples and Standard I. Bone fragments, organic material and idiomorphic mineral phases (in this case mica mineral biotite) can be precisely detected by $\mu \mathrm{CT}$. When examining the thin sections, it was not clear whether they were cavities or non-plastic inclusions. But it is quite clear from the $\mu \mathrm{CT}$ scans that straws, present only as imprints, can be identified and are non-interchangeable with cavities due to e.g., manufacturing techniques (Figure 6, middle).

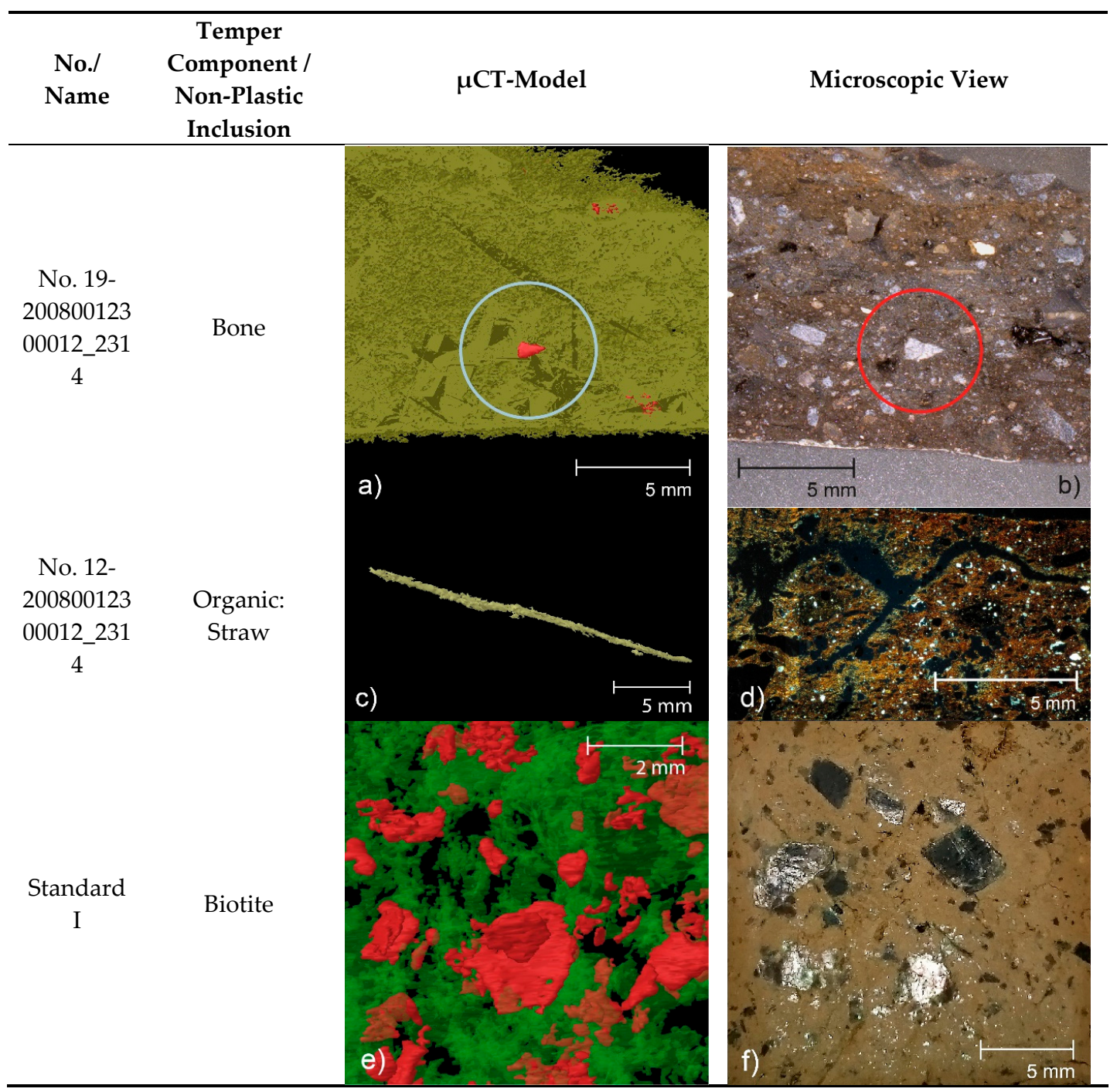

Figure 6. Examples of temper components and non-plastic inclusion in two neolithic samples and Standard I. (a,b) bone fragment in sample No. 19-20080012300012_2314 (a: X-ray microtomography $(\mu \mathrm{CT})$ reconstruction, b: cut surface); (c,d) straw as non-plastic inclusion in No. 12-20080029600009_2008 (c: $\mu \mathrm{CT}$ reconstruction, $\mathrm{d}$ : photomicrograph of thin section); $(\mathbf{e}, \mathbf{f})$ mineral phase biotite (e: $\mu \mathrm{CT}$ reconstruction, biotite is in red, f: polished surface). 
The advantage of $\mu \mathrm{CT}$ compared to thin-section analysis is not only the non-destructive analysis of the samples. Thin sections allow only a small 2D section of the sample, but $\mu \mathrm{CT}$ scans allow the entire object to be analysed. However, it is only possible to differentiate between temper components as long as the density of various components can be distinguished in grey values. The grey values will then provide information about the quantity of the phases or components and the objects can be visualized in a 2D and 3D model.

The $\mu \mathrm{CT}$ scans of the neolithic samples provided in addition information on the porosities of the ceramic structures, or more generally of sample structures. Can porosities be used to indicate the typological classification of the finds or even the type or shape of the vessel?

Table 5 displays 3D reconstructions of X-ray microtomography scans of the investigated neolithic samples, cross sections as 2D reconstructions, information about the total objects' volumes and the porosities of those volumes. Data processing was done with the SkyScan software CTAn and CTVol. Temper components as well as the various shapes of the voids are visible in the 2D cross sections. In addition, information about the typological horizons and vessel types are given in Table 5 (see also Table 1 for more details).

Table 5. X-ray microtomography scans of neolithic samples and morphometric information.

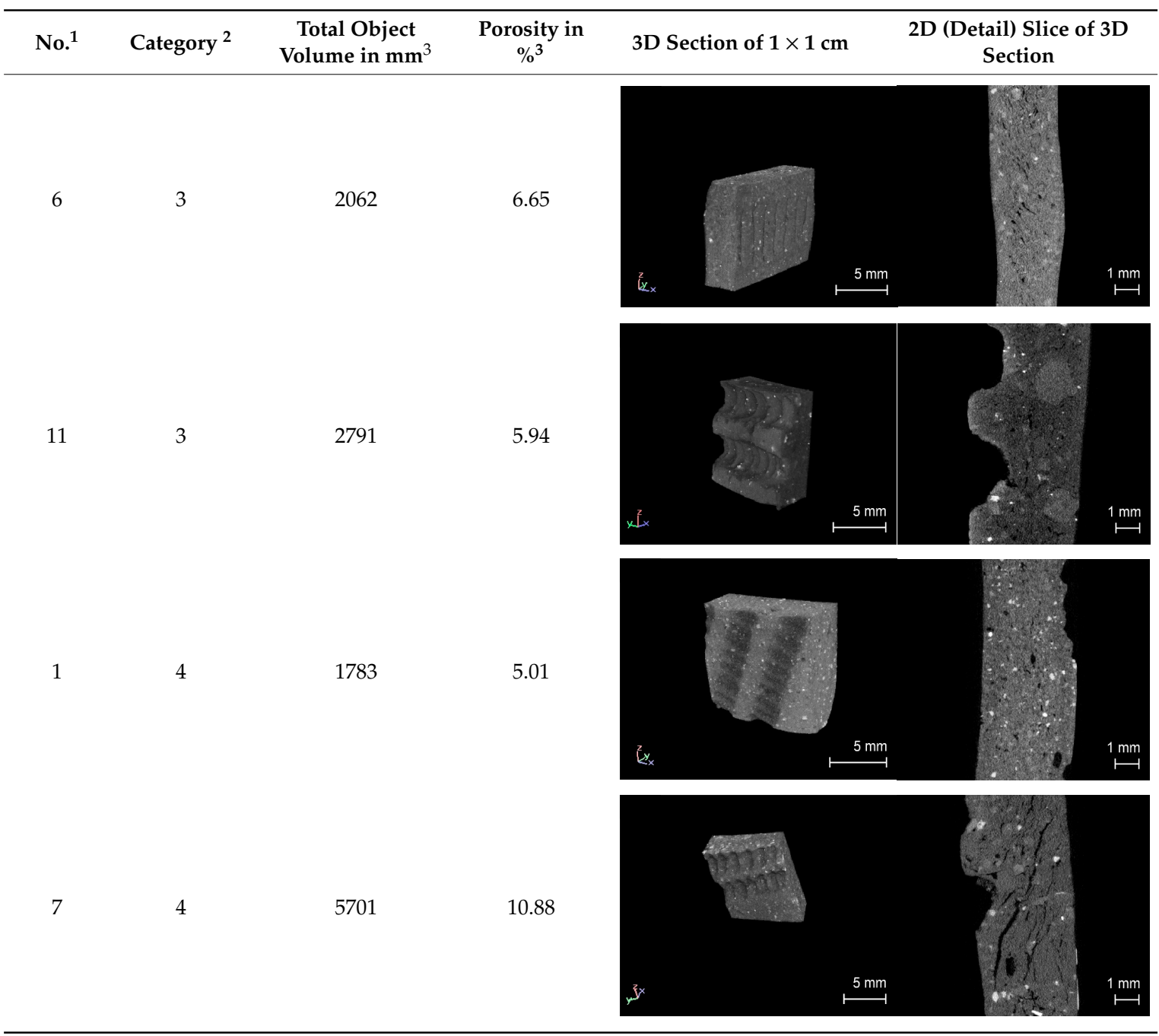


Table 5. Cont.

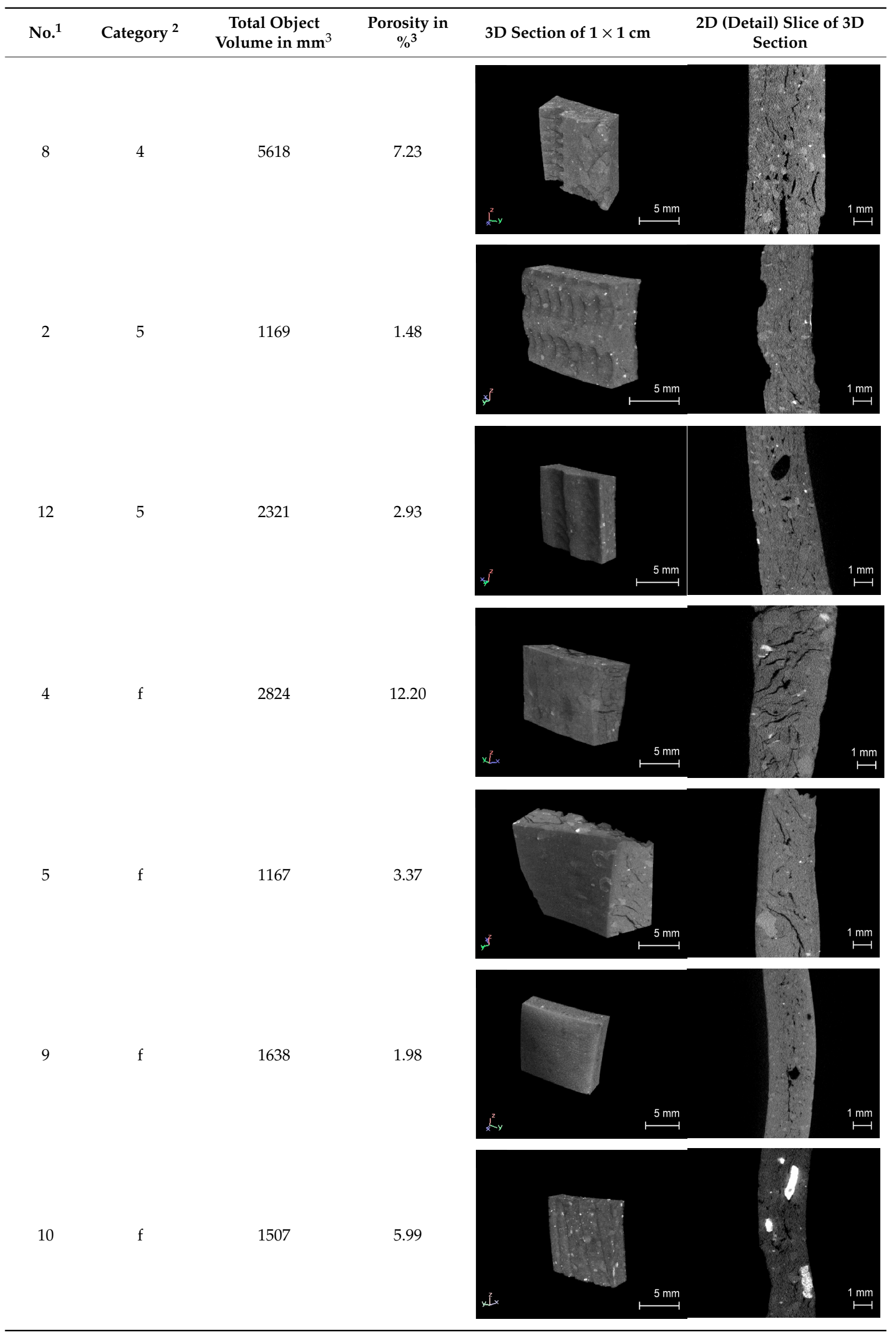


Table 5. Cont.

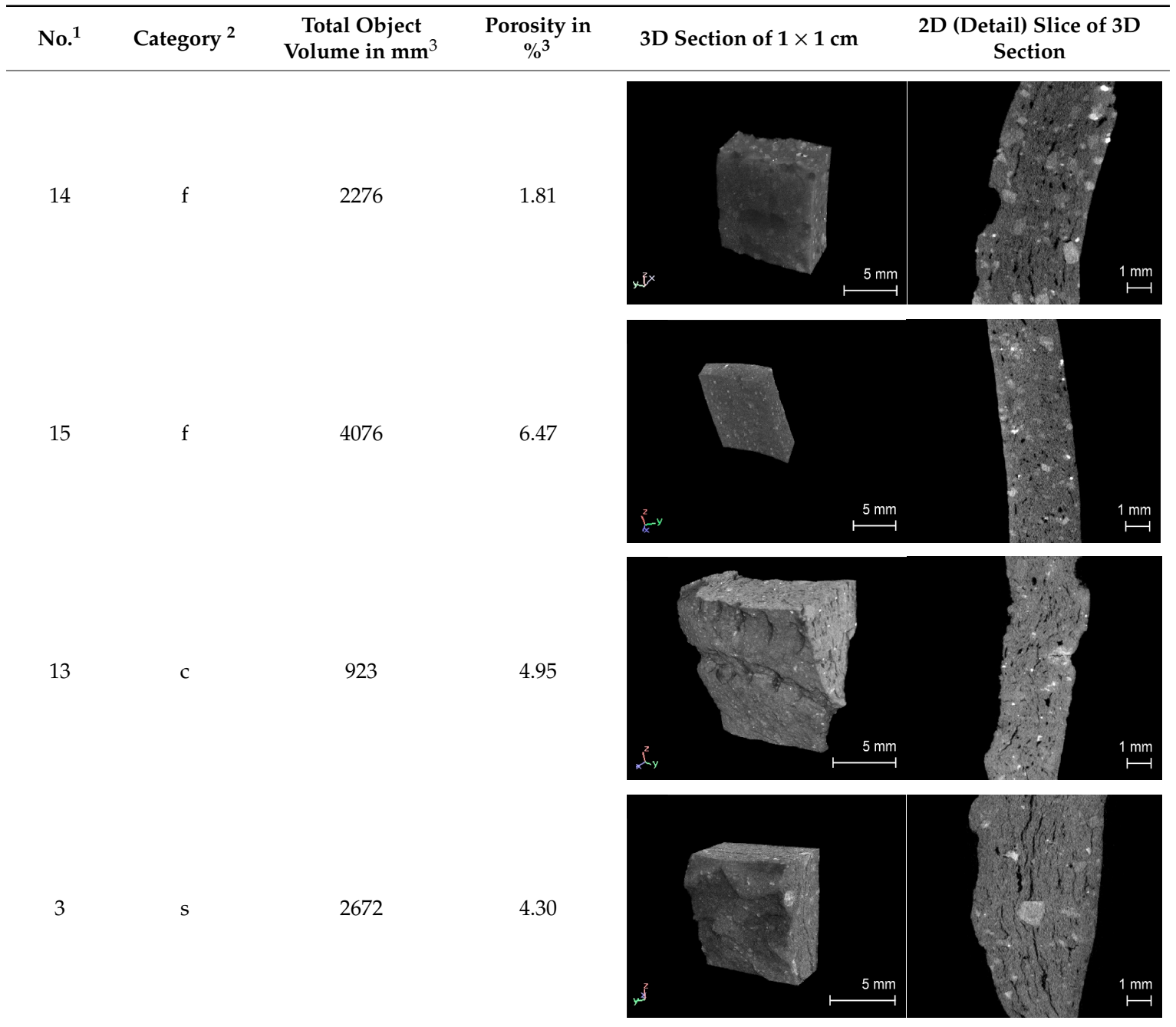

${ }^{1}$ Consecutive number (No.) corresponds to Table $1 .{ }^{2}$ Categories refer to the typochronological classification of the pottery according to the dating horizons $3,4,5$ and types (see Menne, 2018, for more details [17]). ${ }^{3}$ Porosity is total porosity of each scanned sherd, temper components are visible in 2D (detail); please note: sample no. 19 (20080012300012_2314, WP 43, s) is not listed as only a 3D reconstruction exist and no porosity analyses was made.

Only finds of horizons 3 to 5 were selected in this study as those provide the most precise typochronological classification of finds (see [17], for more details). Although the number of investigated finds are small (7 finds assigned to horizons and 8 finds with only known types of the vessels as those finds are stratigraphically unclassifiable), differences between the different categories of the horizons can be identified. The porosities of finds of horizon 4 (5.01, 7.33, 10.88, i.e., on average 7.74\%; are slightly higher than those of horizon 3 (5.94, 6.65, average 6.30\%). Finds of horizon 5 have the smallest porosities $(1.48 \%, 2.93 \%, 2.21 \%)$. The present study shows that the younger samples have a lower porosity compared to the older ones. This may be related to a change in production technology in the younger phase of TRB, whereby the vessels may have become more solid.

The collar flask has a porosity of $4.95 \%$ and the funnel beakers have a porosity of $1.81-12.20 \%$ $(n=6)$, on average $5.30 \%$; the pottery of the single-grave period has a porosity of $4.30 \%$. The comparison of funnel beakers and bowls (all from categories 3 to 5) shows similar porosities but also reflects the large variations in the porosities of the individual vessel types (funnel beaker $5.30 \pm 3.91 \%$; bowls $5.73 \pm 3.06 \%$ ). Based on the limited data set of our study, it is not possible to differentiate between vessel types and possible differences in production technology of manufacturing. For future studies it remains to be examined whether the use of the vessel types (e.g., beaker for liquid contents 
or bowls for solid contents) can be distinguished on the basis of porosity. This might indicate whether different clay mixtures have been used at the same time intentionally during a typological horizon.

Comparison of the porosities in consideration of the three sites E2, GB7 and WP43 reveal that the ceramics of GB 7 have porosities of 1.81-6.47\% (n=5), on average $4.42 \%$, of E2 1.98-10.88\% (n = 5), on average $6.55 \%$, and WP43 $1.48-12.20 \%(n=5)$, on average $5.27 \%$ (see Table 5 ). The average porosities in E2 are $2.13 \%$ higher than in GB7 and 1.28\% higher than in WP43. This might be an indication of the different production techniques used at the different sites. Despite the small number of samples, it is not possible to say whether the porosities indicate site-specific production methods. The observed trend requires a larger sample size to be tested in order to confirm this tendency.

Even though only 15 finds were studied in detail by $\mu \mathrm{CT}$, and the great potential of non-destructive $\mu \mathrm{CT}$ method is obvious for distinguishing various finds regarding their typochronology, the sample number is far too small to clearly keep the sites apart and also to provide evidence for different production techniques. More samples have to be investigated to find out if there are exact differences in porosity in bowls, amphorae and cups and to provide answers to questions like "Could the different types of vessels possibly have been produced using different techniques?" or "Could this have been part of the burial rite?".

\section{Concluding Remarks and Outlook}

Ceramics can be either examined non-destructively or through destruction caused by analytical procedures. These two concepts have been explored and combined by using different methodologies.

A common procedure in archaeology is to partly destroy the objects for analysis. But often the ultimate examination is only based on thin sections and portable XRF for basic geochemical analysis. This leaves a lot of unused potential for a detailed examination of the materials. The aim of this study is to evaluate the quality and limits of measurement techniques like portable XRF, WD-XRF, and $\mu \mathrm{CT}$ and to apply constraints on their reliability and applicability for archaeological interpretations of ceramic studies in order to draw conclusions about, for example, the production technique of the finds. This was done in four steps:

1. Destructive method by thin sections and macroscopic investigation

Using the non-destructive method of macroscopic investigation, information on temper components can be obtained at first glance. But more detailed and reliable information on ceramic components with thin-section petrography as the standard method requires the partial destruction of samples.

2. Non-destructive method of portable XRF

A first impression of the geochemical structure of the sample can be gained by portable XRF at the fresh fracture, if present. However, it must be considered that the larger the grain size of the components of the ceramic, the more the geochemical data can be falsified. It turned out that the measurements of the fresh fractures did not provide satisfactorily precise results. But it is beyond question that portable XRF gives a quick overview of the chemical composition of ceramics and can be used both non-destructively and destructively. The portable analyses on pulverized samples are a cost-effective and fast alternative to wavelength-dispersive $\mathrm{X}$-ray fluorescence (WD-XRF).

3. Destructive method by pulverized samples with portable XRF and WD-XRF

In comparison to portable XRF measurements, WD-XRF provides more precise data on the geochemical composition. However, WD-XRF is often not possible for cost reasons. The direct comparison of aliquots of identical pulverized samples measured with portable XRF and WD-XRF revealed reliable portable XRF concentration data of $\mathrm{K}, \mathrm{Fe}, \mathrm{Rb}, \mathrm{Ti}, \mathrm{V}, \mathrm{Y}, \mathrm{Zn}$, and $\mathrm{Zr}$, but other elements need to be corrected. Although portable XRF provides reliable data, there are limitations in the performance and evaluation of measurements. Multiple measurements of standard GBW04711 over a period of time of 5 years showed that the quality of the measurements strongly depends on the maintenance of 
both software and hardware as well as on the "Aging Effect" of the X-ray tube. Regular calibration of portable XRF devices is of crucial importance.

4. Non-destructive method of $\mu \mathrm{CT}$

The non-destructive method of $\mu \mathrm{CT}$ is a suitable complement to the conventional archaeometric method for the identification of the components using thin sections. Cross sections based on $\mu \mathrm{CT}$ scans even allow 2D insights at different individually selected parts of the sherds. Quantitative information regarding modal abundances of phases and porosities of the ceramics can be obtained by $\mu \mathrm{CT}$ scans (3D). Even characterisation of the organic temper components and non-plastic inclusions is possible.

The studied neolithic ceramics showed slight differences in porosities. The younger ceramics have lower porosities compared to the older ones. With regard to the various vessel types, differentiation is not possible due to the large variation of porosities in individual vessel types. The same is true for a differentiation based on the sites. The porosities of the 15 neolithic ceramics studied disclosed neither type-specific nor site-specific manufacturing techniques. However, the great potential of the $\mu \mathrm{CT}$ technique to extract valuable information needed by archaeologists to group samples and, if applicable, to deduce details on manufacturing is obvious.

Supplementary Materials: The following are available online at http://www.mdpi.com/2075-163X/10/10/931/s1. Table S1: Raw data_portable XRF: Appendix_A_Data_pedXRF_Menne et al.

Author Contributions: Investigation, J.M., A.H., and C.H.; formal analysis, J.M. and C.H.; resources, J.M.; visualization, J.M., and C.H.; writing — original draft preparation, J.M. and A.H. All authors have read and agreed to the published version of the manuscript.

Funding: This research received no external funding.

Acknowledgments: We would like to offer our special thanks to the following Institutes for their assistance and technical support with the analysis of the data: Institute of Mineralogy and Petrography, University Hamburg (WD-XRF); GEOMAR Kiel (thin-section microscopy). Stefan Dreibrodt, Brendan Ledwig, Jan Thomsen, and Katrin Struckmeyer are thanked for their intense discussion, technical support and helpful comments as well proof reading the article. Marianne Talma kindly provided her data of the standard measurements of the new X-ray tube (portable XRF (2019)), which we were allowed to integrate into our results. Furthermore, we want to thank Andrea Kaltofen (Kommunale Bodendenkmalpflege, Landkreis Emsland, Lower Saxony, for her permission to study and sample the ceramics. Last but not least we thank four anonymous referees for their comments.

Conflicts of Interest: The authors declare no conflict of interest.

\section{References}

1. Behrendt, S.; Mielke, D.P.; Tagle, R. Provenienzuntersuchungen im Vergleich-Neue Wege zur archäometrischen Untersuchung phönizischer Keramik. Madr. Mitt. 2012, 53, 187-219.

2. Brorsson, T.; Blank, M.; Fridén, I. Mobility and exchange in the Middle Neolithic: Provenance studies of Pitted Ware and Funnel Beaker pottery from Jutland, Denmark and the west coast of Sweden. J. Archaeol. Sci. Rep. 2018, 20, 662-674. [CrossRef]

3. Ceccarelli, L.; Rossetti, I.; Primavesi, L.; Stoddart, S. Non-destructive method for the identification of ceramic production by portable X-rays Fluorescence (pXRF). A case study of amphorae manufacture in central Italy. J. Archaeol. Sci. Rep. 2016, 10, 253-262. [CrossRef]

4. Daszkiewicz, M.; Schneider, G. Möglichkeiten und Grenzen zerstörungsfreier Analysen von Keramik mit pXRF. In Archäometrie und Denkmalpflege 2012, Metalla Sonderheft 5; Schlütter, F., Greiff, S., Prange, M., Eds.; Bergbaumuseum Bochum: Bochum, Germany, 2012; pp. 167-170.

5. Daszkiewicz, M.; Schneider, G.; Schmid, S.G.; Bobryk, E. Grouping of Nabataean Pottery from Petra (Jordan) Using PXRF and Other Techniques. In Archäometrie und Denkmalpflege 2013, Metalla Sonderheft 6; Hauptmann, A., Mecking, O., Prange, M., Eds.; Bergbaumuseum Bochum: Bochum, Germany, 2013; pp. 138-142.

6. Frahm, E. Ceramic studies using portable XRF: From experimental tempered ceramics to imports and imitations at Tell Mozan, Syria. J. Archaeol. Sci. 2018, 90, 12-38. [CrossRef]

7. Frankel, D.; Webb, J.M. Pottery production and distribution in prehistoric Bronze Age Cyprus. An application of pXRF analysis. J. Archaeol. Sci. 2012, 39, 1380-1387. [CrossRef] 
8. Helfert, M. Die portable energiedispersive Röntgenfluoreszenzanalyse (P-ED-RFA)—Studien zu methodischen und analytischen Grundlagen ihrer Anwendung in der archäologischen Keramikforschung. In Naturwissenschaftliche Analysen vor- und Frühgeschichtlicher Keramik III. Methoden, Anwendungsbereiche, Auswertungsmöglichkeiten UPA 238; Ramminger, B., Stilborg, O., Eds.; Habelt: Bonn, Germany, 2013; pp. $14-47$.

9. Karacic, S.; Osborne, J.F. Eastern mediterranean economic exchange during the iron Age: Portable x-ray fluorescence and neutron activation analysis of cypriot-style pottery in the amuq valley, Turkey. PLoS ONE 2016, 11, e0166399. [CrossRef]

10. Ramminger, B.; Stilborg, O. (Eds.) Naturwissenschaftliche Analysen vor- und Frühgeschichtlicher Keramik III. Methoden, Anwendungsbereiche, Auswertungsmöglichkeiten, UPA 238; Habelt: Bonn, Germany, 2013.

11. Shugar, A.N.; Mass, J.L. (Eds.) Handheld XRF for Art and Archaeology; Studies in Archaeological Sciences 3 Leuven University Press: Leuven, Belgium, 2012; pp. 423-448.

12. Behrendt, S.; Mielke, D.P.; Tagle, R. Die portable Röntgenfluoreszenzanalyse (p-RFA) in der Keramikforschung: Grundlagen und Potenzial. Restaur. Archäologie. Konserv. Restaur. Technol. Archäometrie 2012, 5, 93-111.

13. Helfert, M.; Böhme, D. Herkunftsbestimmung von römischer Keramik mittels portabler energiedispersiver Röntgenfluoreszenzanalyse (P-ED-RFA)—Erste Ergebnisse einer anwendungsbezogenen Teststudie. In Naturwissenschaftliche Analysen vor- und Frühgeschichtlicher Keramik I. Methoden, Anwendungsbereiche, Auswertungsmöglichkeiten UPA 176; Ramminger, B., Stilborg, O., Eds.; Habelt: Bonn, Germany, 2010; pp. 11-30.

14. Helfert, M.; Mecking, O. Möglichkeiten und Grenzen der portablen RFA zur Herkunftsbestimmung von Keramik. In Archäometrie und Denkmalpflege 2010, Metalla 3; Hahn, O., Hauptmann, A., Modarressi-Therani, D., Prange, M., Eds.; Bergbaumuseum Bochum: Bochum, Germany, 2010; pp. 107-109.

15. Magetti, M. Chemical Analyses of Ancient Ceramics: What for? Chimia 2001, 55, 923-930.

16. Schultze, E.; Liubichev, M.V.; Daszkiewicz, M.; Bobryk, E.; Schneider, G. (Eds.) Archaeoceramological Studies of Pottery from Voitenke Chernyakhov culture (Ukraine). LRCW3. Late Roman Coarse Wares, Cooking Wares and Amphorae in the Mediterranean. Archaeology and archaeometry. Comparison between western and eastern Mediterranean. BAR Int. Ser. 2010, 2185, 1023-1033.

17. Menne, J. Keramik aus Megalithgräbern in Nordwestdeutschland. Interaktionen und Netzwerke der Trichterbecherwestgruppe; Frühe Monumentalität und soziale Differenzierung 16; Habelt: Bonn, Germany, 2018.

18. Behrendt, S.; Mielke, D.P.; Tagle, R. Provenienzuntersuchungen im Vergleich-Neue Ansätze zur Klassifizierung von Keramik. In Archäometrie und Denkmalpflege 2010, Metalla 3; Hahn, O., Hauptmann, A., Modarressi-Therani, D., Prange, M., Eds.; Bergbaumuseum Bochum: Bochum, Germany, 2010; pp. 113-115.

19. Böhme, D. Portable XRF-Möglichkeiten und Grenzen. In Archäometrie und Denkmalpflege 2010, Metalla 3; Hahn, O., Hauptmann, A., Modarressi-Therani, D., Prange, M., Eds.; Bergbaumuseum Bochum: Bochum, Germany, 2010; pp. 26-28.

20. Helfert, M.; Mecking, O.; Lang, F.; Kaenel, H.-M. Neue Perspektiven für die Keramikanalytik. Zur Evaluation der portablen energiedispersiven Röntgenfluoreszenzanalyse (P-ED-RFA) als neues Verfahren für die geochemische Analyse von Keramik in der Archäologie. Frankf. Elektron. Rundsch. Altert. 2011, 14, 1-30.

21. Schneider, G.; Daszkiewicz, M. Testmessungen mit einem tragbaren Gerät für engerdispersive Röntgenfluoreszenz (P-XRF) zur Bestimmung der chemischen Zusammensetzung archäologischer Keramik. In Archäometrie und Denkmalpflege 2010, Metalla 3; Hahn, O., Hauptmann, A., Modarressi-Therani, D., Prange, M., Eds.; Bergbaumuseum Bochum: Bochum, Germany, 2010; pp. 110-112.

22. Daszkiewicz, M.; Schneider, G. Klassifizierung von Keramik durch Nachbrennen von Scherben. Z. Schweiz. Archäologie Kunstgesch. 2001, 58, 25-32.

23. Brindley, A.L. The Typochronology of TRB West Group Pottery. Palaeohistoria 1986, 28, 93-132.

24. Mennenga, M. Zwischen Elbe und Ems. Die Siedlungen der Trichterbecherkultur in Nordwestdeutschland; Frühe Monumentalität und soziale Differenzierung 13; Habelt: Bonn, Germany, 2017.

25. Kramer, A.; Mennenga, M.; Nösler, D.; Jöns, H.; Bittmann, F. Neolithic Settlement and Land Use History in Northwestern Germany-First Results from an Interdisciplinary Research Project. In Siedlung, Grabenwerk, Großsteingrab. Studien zu Gesellschaft, Wirtschaft und Umwelt der Trichterbechergruppen im Nördlichen Mitteleuropa. Frühe Monumentalität und soziale Differenzierung 2; Hinz, M., Müller, J., Eds.; Habelt: Bonn, Germany, 2012; pp. 317-336.

26. Kramer, A.; Bittmann, F.; Nösler, D. New insights into vegetation dynamics and settlement history in Hümmling, north-western Germany, with particular reference to the Neolithic. Veg. Hist. Archaeobotany 2014, 23, 461-478. [CrossRef] 
27. Behre, K.-E. Die Einengung des neolithischen Lebensraumes in Nordwestdeutschland durch klimabedingte Faktoren: Meeresspiegelanstieg und großflächige Ausbreitung von Mooren. In Klimaveränderung und Kulturwandel in Neolithischen Gesellschaften Mitteleuropas, 6700-2200 v. Chr; RGZM-Tagungen 1; Gronenborn, D., Alram-Stern, E., Eds.; RGZM: Mainz, Germany, 2005; pp. 209-220.

28. Bakker, R. The emergence of agriculture on the Drenthe Plateau. A Palaeobotanical Study Supported by High-Resolution 14C Dating; DGUF Archäologische Ber; DGUF-Verlag: Kerpen, Germany, 2003.

29. Castel, I.I.Y. Late Holocene eolian drift sands in Drenthe (The Netherlands). In Netherlands Geographical Studies 133; Koninklijk Nederlands Aardrijkskundig Genootschap: Amsterdam/Utrecht, The Netherlands, 1991.

30. Sprockhoff, E. Atlas der Megalithgräber Deutschlands; Teil 3: Niedersachsen-Westfalen; Habelt: Bonn, Germany, 1975; Volumes 90-106, pp. 107-112.

31. Schlicht, E. Vorgeschichte des Hümmlings. 1. Teil. Die Steinzeit. Ph.D. Thesis, University Kiel, Kiel, Germany, 1941.

32. Schlicht, E. Arbeitsberichte und Mitteilungen. Urgeschichtliche Denkmalpflege. Fundbericht für das Jahr 1953. JbEHB 1954, 2, 193-195.

33. Schlicht, E. Untersuchungen an zerstörten Megalithgräbern. In Zur Ur- und Frühgeschichte Nordwestdeutschlands. Neue Untersuchungen aus dem Gebiete zwischen Ijssel und Ostsee. Festschrift K. H. Friesen; Zylmann, P., Ed.; Lax: Hildesheim, Germany, 1956; pp. 69-70.

34. Schlicht, E. Urgeschichtliche Denkmalpflege. Fundbericht für die Jahre 1954 und 1955. JbEHB 1957, 4, 137-139.

35. Schlicht, E. Die Funde aus dem Megalithgrab 2 von Emmeln, Kreis Meppen; Studien zur Keramik der Trichterbecherkultur im Gebiet zwischen Weser und Zuidersee. Göttinger Schriften zur Vor- und Frühgeschichte 9; Seminar für Ur- und Frühgeschichte der Georg-August-Universität: Wachholtz Neumünster, Germany, 1968.

36. Schlicht, E. Die Funde aus dem Steingrab 2 von Emmeln, Kr. Meppen. Germania 1968, 43, 351-354.

37. Schlicht, E. Das Megalithgrab 7 von Gross Berssen, Kreis Meppen. Studien zur Keramik der Trichterbecherkultur im Gebiet zwischen Weser und Zuidersee. Göttinger Schriften zur Vor-und Frühgeschichte 12; Seminar für Ur- und Frühgeschichte der Georg-August-Universität: Wachholtz Neumünster, Germany, 1972.

38. Schlicht, E. Meine Ausgrabungen im Rahmen der Emslanderschließung. JbEHB 1982, 28, $29-30$.

39. Fansa, M. Die Keramik der Trichterbecherkultur aus dem Megalithgrab 1 von Ostenwalde, Kreis Aschendorf-Hümmling. Ein Versuch zur Klassifikation und Dokumentation steinzeitlicher Keramik. Neue Ausgrab. Forsch. Niedersachs. 1978, 12, 33-77.

40. Tempel, W.D. Bericht über die Ausgrabung des Megalithgrabes I in Ostenwalde, Gemeinde Werlte, Kreis Aschendorf-Hümmling. Neue Ausgrab. Forsch. Niedersachs. 1978, 12, 1-31.

41. Struckmeyer, K. Keramikanalysen an Funden aus Emmeln 2, Groß Berßen 7 und Werpeloh 43, Ldkr. Emsland. In Keramik aus Megalithgräbern in Nordwestdeutschland. Interaktionen und Netzwerke der Trichterbecherwestgruppe; Frühe Monumentalität und soziale Differenzierung 16; Menne, J., Ed.; Habelt: Bonn, Germany, 2018; pp. 315-319.

42. Struckmeyer, K. Keramikanalysen an Funden aus Flögeln, Ldkr. Cuxhaven, Lavenstedt, Ldkr. Rotenburg (Wümme), und Visbek, Ldkr. Vechta. In Zwischen Elbe und Ems. Die Siedlungen der Trichterbecherkultur in Nordwestdeutschland; Frühe Monumentalität und soziale Differenzierung 13; Mennenga, M., Ed.; Habelt: Bonn, Germany, 2017; pp. 421-435.

43. Struckmeyer, K. Archäometrische Analysen an Keramikmaterial aus Nordwestdeutschland. Siedl. Küstenforschung Südlichen Nordseegebiet 2015, 38, 107-121.

44. Struckmeyer, K. Archäometrische Analysen an Keramik aus dem Megalithgrab “Denghoog” (LA 85). In Denghoog-Großeibstadt-Rastorf; Frühe Monumentalität und soziale Differenzierung 5; Wunderlich, M., Koch, J.K., Dieck, P., Eds.; Habelt: Bonn, Germany, 2014; pp. 127-132.

45. Struckmeyer, K. Archaeometric Analysis of Pottery Technology in the Funnel Beaker Culture. A case study: Tannenhausen, East Frisia (Germany). J. Neolithic Archaeol. 2013, 15, 55-63.

46. Baier, I.; Struckmeyer, K. Tonangebend! Archäometrische Methoden in der Keramikanalyse. Archäologie Niedersachs. 2017, 20, 97-100.

47. Nösler, D.; Struckmeyer, K.; Jöns, H. Neue Forschungen zur Tradition, Technologie und Kommunikationsstrukturen des Töpferhandwerks der Trichterbecherkultur-Erste Ergebnisse archäometrischer Untersuchungen. In Siedlung, Grabenwerk, Großsteingrab. Studien zu Gesellschaft, 
Wirtschaft und Umwelt der Trichterbechergruppen im nördlichen Mitteleuropa; Frühe Monumentalität und soziale Differenzierung 2; Hinz, M., Müller, J., Eds.; Habelt: Bonn, Germany, 2012; pp. 463-471.

48. Dreibrodt, S.; Furholt, M.; Hofmann, R.; Hinz, M.; Cheben, I. P-ed-XRF-geochemical signatures of a 7300 year old Linear Band Pottery house ditch fill at Vráble-Vel'lké Lehemby, Slovakia-House inhabitation and post-deposital processes. Quat. Int. 2017, 438, 131-143. [CrossRef]

49. Hunt, A.M.W.; Speakman, R.J. Portable XRF analysis of archaeological sediments and ceramics. J. Archaeol. Sci. 2015, 53, 626-638. [CrossRef]

50. Speakman, R.J.; Little, N.C.; Creel, D.; Miller, M.R.; Inanez, J.G. Sourcing ceramics with portable XRF spectrometers? A comparison with INAA using Mimbres pottery from the American Southwest. J. Archaeol. Sci. 2011, 38, 3483-3496. [CrossRef]

51. Daszkiewicz, M.; Schneider, G. Analysis of chemical composition of ancient ceramics. Novensia 2014, 25, 200-206.

52. Schiavon, N.; Soria, V.; Arruda, A.M.; Beltrame, M.; Mirao, J. “Losanga" decorated imitations of Italic Late Republican black gloss tableware from South-Western Iberia: A multi-analytical/microchemical characterization. Microchem. J. 2016, 124, 712-718. [CrossRef]

53. International Atomic Energy Agency. Survey of Reference Materials. Environmentally Related Reference Volumes 2, Materials for Trace Elements, Nuclides and Microcontaminants, IAEA-TECDOC 1996, 880. Available online: https://inis.iaea.org/collection/NCLCollectionStore/_Public/27/059/27059426.pdf (accessed on 21 October 2020).

54. Kahl, W.-A.; Hinkes, R.; Feeser, V.; Holzheid, A. Microfabric and anisotropy of elastic waves in sandstone-An observation using high-resolution X-ray microtomography. J. Struct. Geol. 2013, 49, 35-49. [CrossRef]

55. Daszkiewicz, M.; Schneider, G.; Baranowski, M.; Petrut, D.; Rusu-Bolindeţ, V.; Man, N. Moesian and Dacian sigillata-Exploring regional patterns. A methodological approach using chemical analysis by WD-XRF and p-ED-XRF. Rei CretariÆ RomanÆ Fautorum Acta 2018, 45, 541-559.

Publisher's Note: MDPI stays neutral with regard to jurisdictional claims in published maps and institutional affiliations.

(C) 2020 by the authors. Licensee MDPI, Basel, Switzerland. This article is an open access article distributed under the terms and conditions of the Creative Commons Attribution (CC BY) license (http://creativecommons.org/licenses/by/4.0/). 